\title{
ASSESSMENT OF IMPACTING THE THIN PROTECTIVE COATINGS ON THE STRESS-STRAIN STATE OF THE CLADDING OF FUEL RODS OF NUCLEAR REACTORS
}

\author{
E.V. Povolotskii ${ }^{1}$, Yu.V. Romashov ${ }^{1,2}$, A.G. Mamalis $^{3}$ \\ ${ }^{1}$ National Technical University “Kharkiv Polytechnic Institute”, Kharkiv, Ukraine; \\ ${ }^{2}$ V.N. Karazin Kharkiv National University, Kharkiv, Ukraine; \\ ${ }^{3}$ Project Center for Nanotechnology and Advanced Engineering, NCSR "Demokritos", \\ Athens, Greece \\ E-mail: yu.v.romashov@gmail.com
}

It is proposed the approach for estimating the impact of thin protective coatings on the stress-strain state of the thick-walled claddings of cylindrical fuel rods considering internal and external pressures from fission products and moving heat carrier in a nuclear reactor core. This approach is used for quantitative estimations the impact of possible thin coatings made from a stainless steel on the stress-strain state of the cladding made from the Zirconiumbased alloy used in the WWER-1000 nuclear reactors. It is shown that thin protective coatings can allow increasing the general strength and reliability of the cladding due to stresses decreasing.

\section{INTRODUCTION}

Possibilities of further improvements of the power nuclear reactors for industrial purposes are significantly limited by the operational abilities of the modern known structural materials especially for claddings of fuel rods, and development the more useful structural materials is the one of the global problem of the modern material science for nuclear engineering $[1,2]$. Using the thin protective coatings is one of effective way to increase the operation reliability of the cladding of fuel rods as shown the modern researches [3,4]. It is interesting that this approach can be imagined the cladding with the protective thin coatings as the composite material (i.e. the material consists of two or more components with clear defined boundaries $[5,6])$ the properties of it will be defined by relations between properties of the main structure of the cladding and its coatings. The specific of neutron-physical process of a core of a nuclear reactor requires the smallest thickness of the thin protective coating as possible, and as the result the thick-walled cladding of fuel rods with thin protective coatings actually is the particular case of the composites with micro- and nanostructures which are seems as one of the most perspective structural materials and have widely researching now $[7,8]$.

Wide industrial employing of the thin protective coatings is significantly bound due to absent the reliable approaches for predicting behavior of the cladding of fuel rods with these thin protective coatings under operational conditions inherent for a core of a nuclear reactor. Really, presence the thin protective coatings on the thick-walled cladding with the wanted suitable effects can lead also to some additional unwanted effects of damaging on the boundary between the coatings and the cladding such as delamination, and the conditions in a core of nuclear reactor (stationary and non-stationary mechanical loadings, temperature gradients, irradiations, wearing, etc.) contribute these damages. The processes in the boundary of structures are the most difficult for researching, especially when the bounded structures have the significantly different properties such as the thick-walled cladding and the thin-walled coatings. This research deals with the important particular problem about estimating the stress-strain state of the cladding of the cylindrical fuel rods considering with presence of the thin protective coating for assessments of impacting these coatings on the mechanical behavior of the cladding under the operational pressures in the core of the nuclear reactor.

\section{TYPICAL DESIGNS OF CLADDINGS}

\section{FOR FUEL RODS OF NUCLEAR REACTORS}

At present, the cylindrical fuel rods are considered as the typical design for the most used and future projects of the pressurized-water nuclear reactors for power industry [9]. The cladding of such fuel rods is made as the circular pipe with the internal radius $a$, the external radius $b$ and with the character length $L$.

For widely used designs of claddings of fuel rods the length and the external radius are satisfied the condition:

$$
L>b \text {. }
$$

For example, the cladding of the fuel rods for the WWER-1000 nuclear reactor the length $L \approx 3800 \mathrm{~mm}$, but external radius $b \approx 4.6 \mathrm{~mm}$ [10].

The thickness of the wall in the typical designs of cladding of fuel rods is lower than $1 \mathrm{~mm}$ (is $0.65 \mathrm{~mm}$ in the WWER-1000 nuclear reactor [10]), and it seems that cladding is the thin-walled structure. At the same time, to establish affiliation to the thin-walled or thick-walled structures it is necessary to compare the relation between the thickness $h$ and the curvature radius $R$ of the middle surface of the structure $[11,12]$ :

$$
\kappa=h / R \text {. }
$$

It is considered $[10,11]$ that for the thin walled structures value (3) must at least satisfy the condition

$$
\kappa<1 / 8 \text {. }
$$

Inequality (3) is formulated to provide the opportunities of the simplification $(1 \pm h) / R \approx 1$ significantly used in the theory of thin shells and plates $[11,12]$. Relation (3) can be represented in the terms of the internal and external radius of a cladding: 


$$
\kappa=2 \frac{b-a}{b+a} .
$$

For the WWER-1000 nuclear reactor we have the sizes $a=3.9 \mathrm{~mm}, b=4.55 \mathrm{~mm}$ [10], which lead (4) to the result $\kappa \approx 1.2 / 8$ that the claddings of the fuel rods using in this nuclear reactor are the thick-walled structures.

The claddings of fuel rods of modern nuclear reactors are made from the Zirconium-based alloys due to the well-known circumstances connected with the neutron-physical properties of the Zirconium principally requiring for building the core of nuclear reactors. For, example, the claddings of the fuel rods used for the WWER-1000 nuclear reactors are made from the Zirconium-based alloy [10]. At the same time, it is wellknown, that the Zirconium-based alloys are subjected to the surface corrosion under the increased temperatures, which can have presence in some local places under the normal operation and necessarily will have presence under the some accidents conditions. Thus, using the thin protective coatings for claddings of fuel rods is purposed to minimize the surface corrosion under the increased temperatures. These protective coatings made from corrosion stable materials and must have the extreme minimal thickness to exclude violation the neutron field in the core of nuclear reactors. Due to these circumstances, using the thin protective coatings for the cladding of fuel rods leads to the structures with interacting between the thick-walled and thin-walled elements.

\section{SCHEMATIZATION OF THE CLADDING CONSIDERING THE THIN COATINGS}

Consideration the cladding of fuel rods under loading from the fission products and the moving heat carrier with effects from the edges and fixing parts and from the thin coatings is in general the complicated problem requires constructing the serious mathematical models as well as numerical methods and computer simulations. To simplify the problem to estimate the qualitative and approximately quantitative effects of presence the thin coatings it is necessary to propose the suitable schematization of the cladding with the thin coatings. Such schematization of claddings considering thin coatings can be constructed on the base of the discussed above specific properties (1)-(3). Really, the inequality (1) allows to use the plane strain hypothesizes well-known in the theory of elasticity [13] to consider the main thick-walled parts of the cladding. Effects from the fission products and the moving heat carrier can be represented by the internal $p_{a}$ and external $p_{b}$ pressures on the cladding, and in this case we actually have the cylindrical cladding with the axial symmetry of the plane strain such as the stress-strain state:

$$
u=u(r), \sigma_{r}=\sigma_{r}(r), \sigma_{\theta}=\sigma_{\theta}(r), \sigma_{z}=-v\left(\sigma_{r}+\sigma_{\theta}\right),(5)
$$

where $u$ is the radial displacement; $r$ is the radial coordinate; $\sigma_{r}, \sigma_{\theta}$, and $\sigma_{z}$ are the radial, circumferential and axial stresses; $v$ is the Poisson's ratio of the cladding material.

The displacement and stresses (5) corresponding to the case of axial symmetry plane strain of the cylinder can be represented using the differential equation and the relations $[13,14]$ :

$$
\begin{gathered}
\frac{d^{2} u}{d r^{2}}+\frac{1}{r} \frac{d u}{d r}-\frac{u}{r^{2}}=0, a<r<b ; \\
\sigma_{r}=\frac{E^{\prime}}{1-v^{\prime 2}}\left(\frac{d u}{d r}+v^{\prime} \frac{u}{r}\right) ; \\
\sigma_{\theta}=\frac{E^{\prime}}{1-v^{\prime 2}}\left(\frac{u}{r}+v^{\prime} \frac{d u}{d r}\right), \quad a \leq r \leq b,
\end{gathered}
$$

where $E^{\prime}=\frac{E}{1-v^{2}}$ and $v^{\prime}=\frac{v}{1-v}$ are the effective Young's modulus and the Poisson's ratio defined corresponding the plane strain hypothesis thru the value $E$ and $v$ of the Young's modulus and the Poisson's ratio of the material of the cladding.

Solution of the differential equation $(6)$ is $[14,15]$ :

$$
u(r)=C_{1} r+\frac{C_{2}}{r},
$$

where $C_{1}$ and $C_{2}$ are the integration constants, which must de find from the boundary conditions defining the stress-strain state at the surfaces $r=a$ and $r=b$.

Using the solution (8), it is possible to represent the stresses (7) as:

$$
\sigma_{r}=\frac{E^{\prime} C_{1}}{1-v^{\prime}}-\frac{E^{\prime}}{1+v^{\prime}} \frac{C_{2}}{r^{2}}, \sigma_{\theta}=\frac{E^{\prime} C_{1}}{1-v^{\prime}}+\frac{E^{\prime}}{1+v^{\prime}} \frac{C_{2}}{r^{2}} .
$$

In the case of the cladding without the thin coatings the boundary conditions considering with the internal $p_{a}$ and external $p_{b}$ pressures are [13-15]:

$$
\begin{gathered}
\frac{E^{\prime}}{1-v^{\prime 2}}\left(\frac{d u}{d r}+v^{\prime} \frac{u}{r}\right)=-p_{a}, \quad r=a, \\
\frac{E^{\prime}}{1-v^{\prime 2}}\left(\frac{d u}{d r}+v^{\prime} \frac{u}{r}\right)=-p_{b}, \quad r=b .
\end{gathered}
$$

Solution (8) with corresponding stresses (9) for the boundary conditions (10) and (11) is well-known in the theory of elasticity [13-15].

It is obviously, that the boundary conditions (10), (11) cannot be used in the case of the claddings with the thin protective coatings. To obtain the boundary conditions for the claddings with the thin protective coatings it is proposed to consider the equilibrium of the cladding near theirs surfaces taking into account both the internal forces of the cladding and of the coating (Fig. 1). Due to the axial symmetry of the problem, it is possible to consider the coatings as the thin cylindrical shells without bending, i.e. on the base of the membrane theory of shells only with the normal internal forces $N_{\theta}$ (Fig. 1) and displacement $w$ in the direction of the normal to the middle surface $[11,12,15]$. The technique of considering the equilibrium of the internal and external surfaces of the cladding (see Fig. 1) is wellknown and widely used in the theory of elasticity and in the theory of the thin shells $[11,12,15]$. As the results of considering the equilibrium of the cladding boundary surfaces, the further relations are obtained:

$$
\frac{E^{\prime}}{1-v^{\prime 2}}\left(\frac{d u}{d r}+v^{\prime} \frac{u}{r}\right)-E_{a} \frac{h_{a}}{R_{a}} \frac{u}{r}=-p_{a}, r=a,
$$




$$
\frac{E^{\prime}}{1-v^{\prime 2}}\left(\frac{d u}{d r}+v^{\prime} \frac{u}{r}\right)+E_{b} \frac{h_{b}}{R_{b}} \frac{u}{r}=-p_{b}, r=b,
$$

where $E_{a}, h_{a}$, and $R_{a}=a-h_{a} / 2$ are the Young's module, the thickness and the middle surface radius of the internal coating; $E_{b}, h_{b}$ and $R_{b}=b+h_{b} / 2$ are the Young's module, the thickness and the middle surface radius of the external coating.

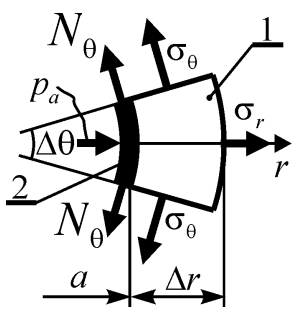

$a$

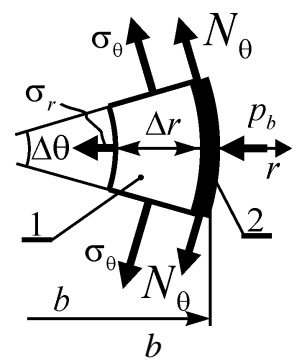

Fig. 1. Equilibrium of the internal (a) and external (b) surfaces of the cladding with the thin protective coating: 1 -domain of the cladding; 2 - domain of the coating

The boundary conditions (12), (13), representing the cladding without the thin coatings as well known in the theory of elasticity [13-15], are the particular cases of the boundary conditions (10), (11) representing the cladding with the thin coatings for zero thickness $h_{a}=0, h_{b}=0$ of these coatings. As seen from the boundary conditions (12), (13), the thin coatings are similar to the continuous spring fixings with the rigidness defined by the Young's modulus, height and the middle surface radius of these coatings. Due to this circumstance, the thin coating must decrease the stresses inside the cladding and this conclusion is corresponded qualitatively with the experimental results [4].

The $C_{1}$ and $C_{2}$ integration constants defining the solutions (8) for the cladding with the thin protective coatings can be find by substituting the solution (8) to the boundary conditions (12), (13) it will lead to the linear algebraic equations:

$$
A_{11} C_{1}+A_{12} C_{2}=-p_{a}, A_{21} C_{1}+A_{22} C_{2}=-p_{b},
$$

where $A_{11}, A_{11}, A_{11}$, and $A_{11}$ are defined as:

$$
\begin{gathered}
A_{11}=\frac{E^{\prime}}{1-v^{\prime}}-\frac{E_{a} h_{a}}{R_{a}} ; A_{12}=-\frac{1}{a^{2}}\left(\frac{E^{\prime}}{1+v^{\prime}}+\frac{E_{a} h_{a}}{R_{a}}\right) ; \\
A_{21}=\frac{E^{\prime}}{1-v^{\prime}}+\frac{E_{b} h_{b}}{R_{b}} ; A_{22}=-\frac{1}{b^{2}}\left(\frac{E^{\prime}}{1+v^{\prime}}-\frac{E_{b} h_{b}}{R_{b}}\right) .
\end{gathered}
$$

Using the equations (14), it is possible to represent the $C_{1}$ and $C_{2}$ integration constants in the form:

$$
C_{1}=\frac{A_{12} p_{b}-A_{22} p_{a}}{A_{11} A_{22}-A_{12} A_{21}}, C_{2}=\frac{A_{21} p_{a}-A_{11} p_{b}}{A_{11} A_{22}-A_{12} A_{21}} .
$$

Thus, the stress-strain state of the cylindrical cladding of fuel rod with the thin protective coatings can be represented in the form (8), (9) in which the integration constants must be defined as (15), (16). It is important what the solution (8), (9), (15), (16) can be used also for the cladding without the protective thin coatings if it is considered the thickness of the coatings are equaled zero.

\section{QUANTITATIVE ESTIMATIONS FOR INFLUENCING THE THIN COATINGS ON THE CLADDING OF FUEL RODS}

To estimate quantitatively influencing of the thin coatings on the stress-strain state of the cladding of fuel rods it is suitable to compare the stress-strain states in the claddings made with and without the thin protective coatings. Next, to have the quantitative estimations of influencing the thin coating on the claddings of fuel rods it will be compared the stress-strain states of the cladding of known fuel rods for the WWER-1000 nuclear reactors made without the protective thin coatings and made with these coatings as possible. Thus, it will be considered the typical cladding of the fuel rods of the WWER-1000 nuclear reactor with the next parameters:

$a=3.855 \mathrm{~mm} ; b=4.55 \mathrm{~mm} ; E=96 \mathrm{GPa} ; v=0.33$;

$$
p_{a}=10 \mathrm{MPa}, p_{b}=16 \mathrm{MPa} \text {. }
$$

It will be estimated the influence of the possible thin protective coatings like in [4] made from the stainless steel with the next value of the Young's modulus:

$$
E_{a}=E_{b}=E_{\text {coat }}=210 \mathrm{GPa} \text {. }
$$

Influencing the thin protective coatings (18) on the stress-strain state of the cladding (17) of fuel rods will be estimated by comparison the stress-strain states in the cladding with different thicknesses $h_{a}$ and $h_{b}$ of the coatings. To obtain the stress-strain states for claddings with and without the thin coatings, it will be used the solution (8), (9), (15), (16) with the effective Young's modulus $E^{\prime}$ and the Poisson's ratio $v^{\prime}$, defining in the comments for the relations (7).

The results for the stress-strain states in the cladding of fuel rods with only internal (Fig. 2), only external (Fig. 3) and both internal and external (Fig. 4) coatings with the different thickness allow to approve that the thin protective coatings are having significant influence on the stresses and displacements in the domain of the cladding.

Comparing the curves presenting on the Fig. 2,a and Fig. 3,a shows that the internal and external coatings are having the different influencing on the radial stresses. This different influencing is inherent to the considered particular case of the cladding (17) due to the considered internal and external pressures are satisfied the inequality

$$
p_{a}<p_{b} .
$$

Really, as well-known in the theory of elasticity [13-15] the radial stresses must satisfy the boundary conditions and must equal to internal and external pressures with negative sign. As the result of this circumstances, for the inequality (18) the absolute values of the radial stresses in the cladding near the internal coating are greater than on the internal coating, as well as the radial stresses in the cladding near the external coating are smaller than on the external coating (see curves 1 on the Fig. 2,a and on the Fig. 3,a). Thus, due to presence the thin coatings, the boundary surfaces of the cladding will be are inside the new composite structure and the absolute values of the radial stresses near the internal coating must be greater, but the absolute values of the radial stresses near the external coating must be smaller. 
Influencing the both internal and external coatings on the radial stresses (see Fig. 4,a) is the result of superposition of the separate influences of the internal and external coatings due to the linear deforming of the cladding and the coatings.
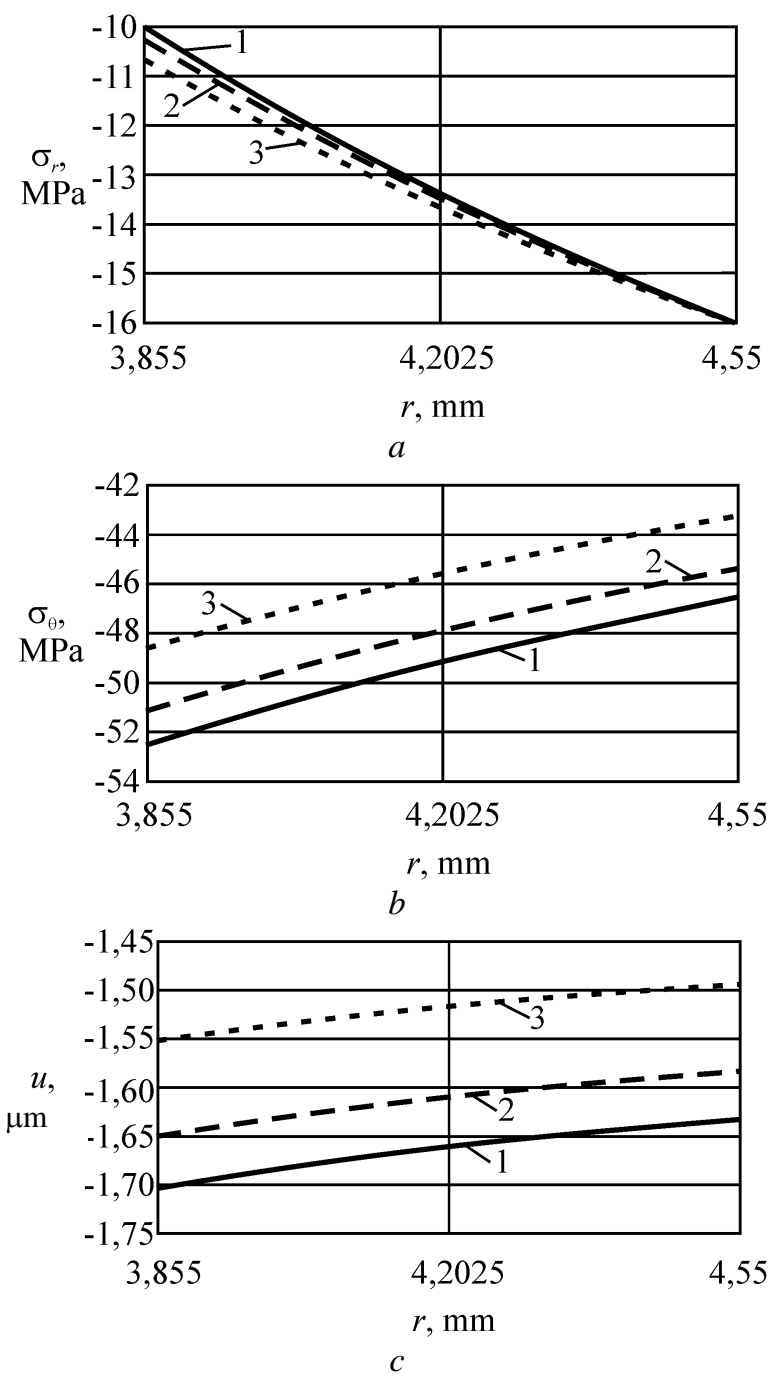

Fig. 2. Influencing the internal coatings on the radial stresses (a), the circumferential stresses (b) and on the radial displacements (c) of the cladding of fuel rods without the external coating:

$1-h_{a}=0 \mu \mathrm{m} ; 2-h_{a}=10 \mu \mathrm{m} ; 3-h_{a}=30 \mu \mathrm{m}$

Influencing the internal and external thin protective coatings on the circumferential stresses and on the radial displacements in the cladding of fuel rods are qualitative similar as can be estimated by comparing the Fig. 2,b,c and the Fig. 3,b. Obtained quantitative results (see Fig. 2,b and Fig. 3,b,c) show that the thin protective coatings lead to decreasing the circumferential stresses and the radial displacements in the cladding of fuel rods and this decreasing are noticeable comparing with increasing the thickness of the coatings. Really, the percent of increasing the sizes of the cladding due to making the thin coatings is significantly smaller than the percent of decreasing of the circumferential stresses and the radial displacements. Influencing of the both internal and external coatings on the circumferential stresses and radial displacements (see Fig. 4,b,c) in the cladding is the result of superposition of the separate influences of the internal and external coatings due to the linear deforming of the cladding and the coatings. Thus, influencing the thin coatings on the stress-strain state of the cladding of fuel rods is fully represented in Figs. 2-4.
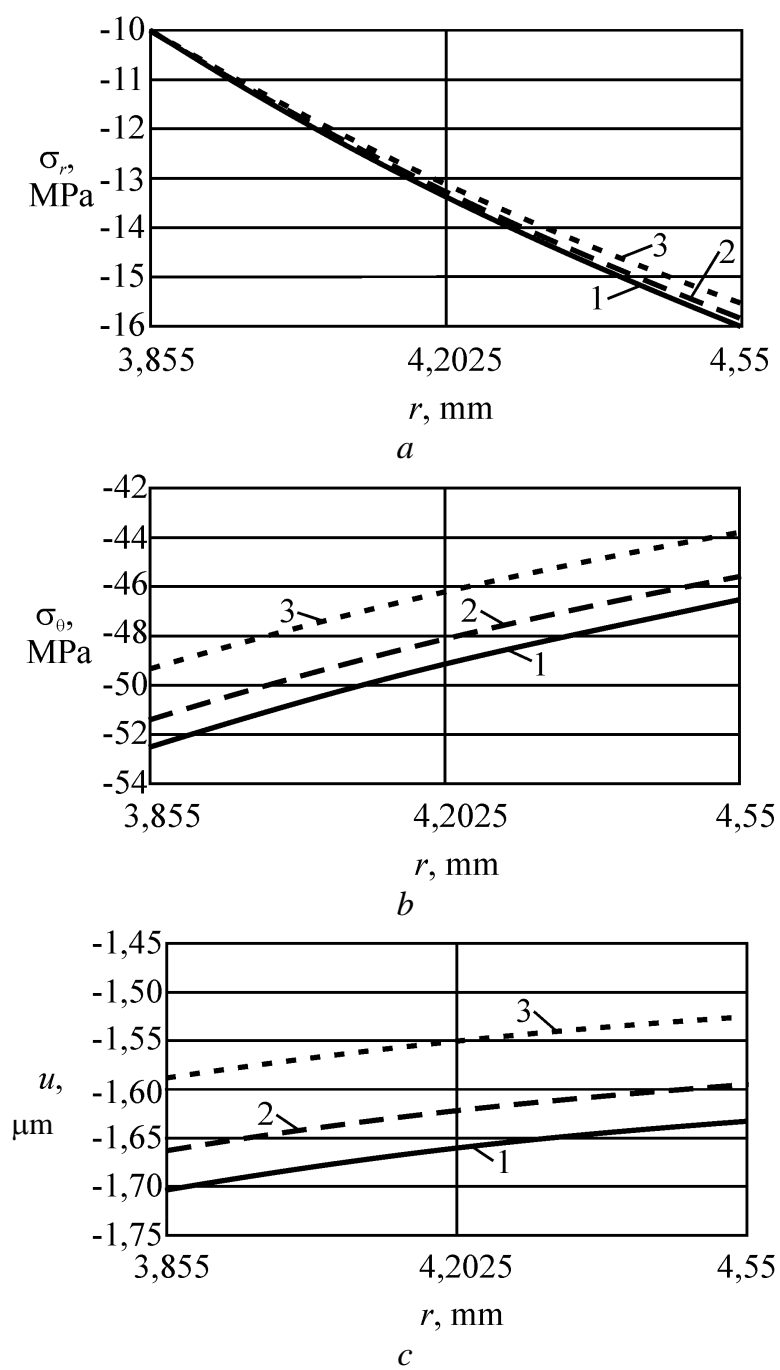

Fig. 3. Influencing the external coatings on the radial stresses (a), the circumferential stresses $(b)$ and on the radial displacements (c) of the cladding of fuel rods without the internal coating:

$1-h_{b}=0 \mu \mathrm{m} ; 2-h_{b}=10 \mu \mathrm{m} ; 3-h_{b}=30 \mu \mathrm{m}$

\section{DISCUSSION THE RESULTS}

Obtained quantitative results (see Figs. 2-4) show that the thin protective coatings have significant influencing on the stress-strain state of the cladding of fuel rods of the WWER-1000 nuclear reactors. Due to this circumstance, to further discussion the obtained results it is interesting to estimate influencing the thin coatings on the strength and the rigidness of the cladding as the structural element of fuel rods.

The operational strength of the cladding can be estimated by value of the von Mises' stress defining as [16]:

$$
\sigma_{i}=\frac{1}{\sqrt{2}} \sqrt{\left(\sigma_{r}-\sigma_{\theta}\right)^{2}+\left(\sigma_{\theta}-\sigma_{z}\right)^{2}+\left(\sigma_{z}-\sigma_{r}\right)^{2}} .
$$

Comparing the maximum stress (20) in the domain of the cladding with the yield point of the cladding's 
material will allow estimating the available operational strength of the cladding.

The displacements on the internal and external surfaces are will be used to characterize the operational rigidness of the cladding:

$$
u_{a}=u(a), u_{b}=u(b) .
$$

The displacements (21) will allow estimating changes in the sizes of the cladding under the operational loadings, i.e. they will represent the rigidness of the cladding.

Results for maximum the von Mises' stress (20) and for the displacements (21) of the cladding of fuel rods are shown on the Fig. 5; it is naturally that obtained results show noticeable depending on the thicknesses of the coatings.

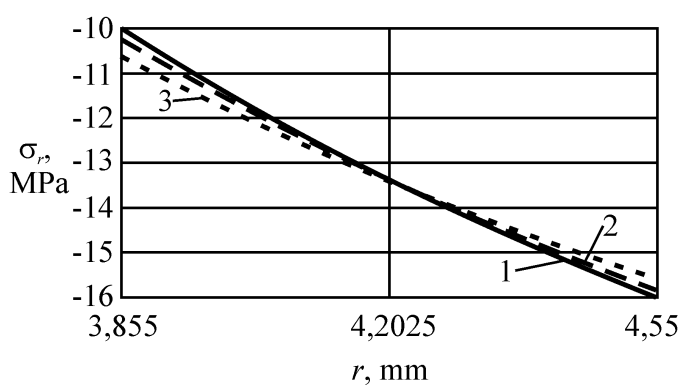

$a$

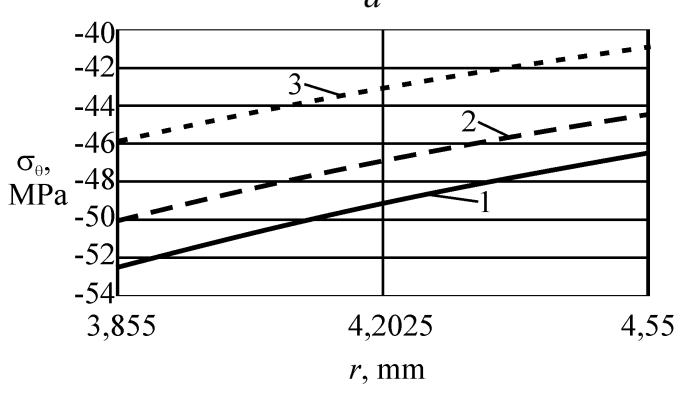

$b$

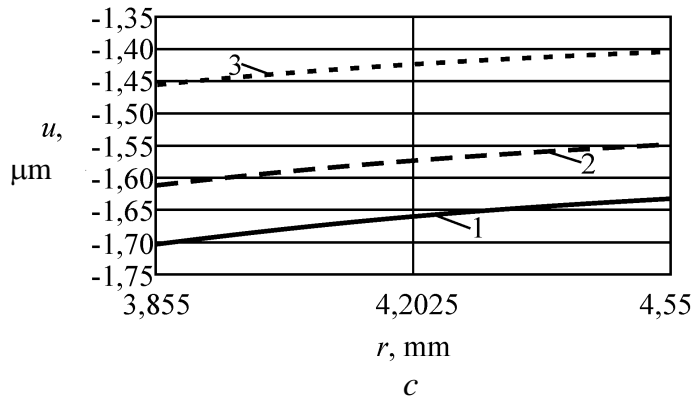

Fig. 4. Influencing both the internal and external coatings on the radial stresses (a), the circumferential stresses (b) and on the radial displacements (c) of the cladding of fuel rods with equal thicknesses $h=h_{a}=h_{b}$ of the external and internal coatings:

$1-h=0 \mu \mathrm{m} ; 2-h=10 \mu \mathrm{m} ; 3-h=30 \mu \mathrm{m}$

Results (see Fig. 5) show that the thin protective coatings have leading to increase the strength and the rigidness of the cladding of fuel rods. It is shown that the internal coating has the more influences on the strength and on the rigidness of the cladding, and this is naturally leads from the boundary conditions (12), (13). Really, influencing of the internal and external thin protective coatings is defined by the values:

$$
E_{a} \frac{h_{a}}{R_{a}} \frac{u(a)}{a}, E_{b} \frac{h_{b}}{R_{b}} \frac{u(b)}{b} .
$$
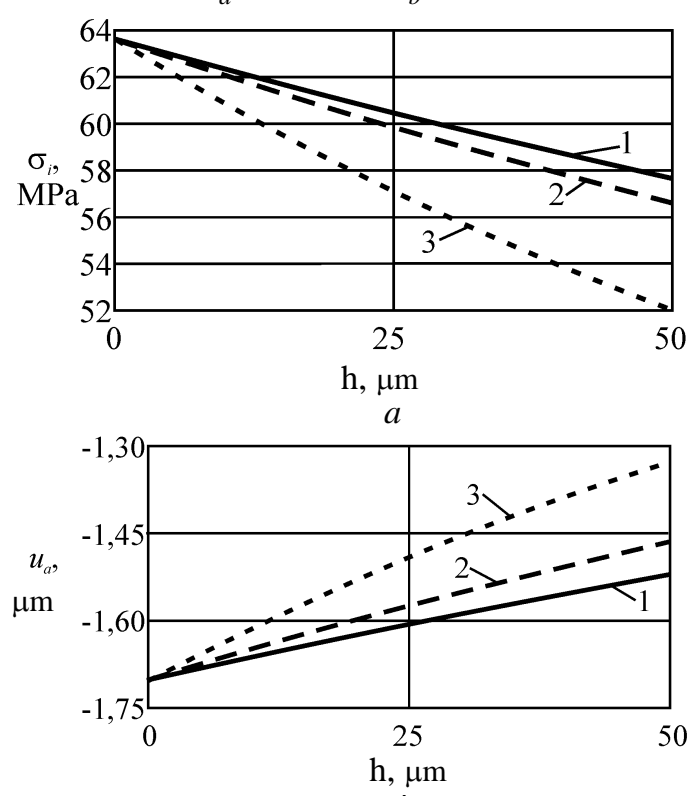

b

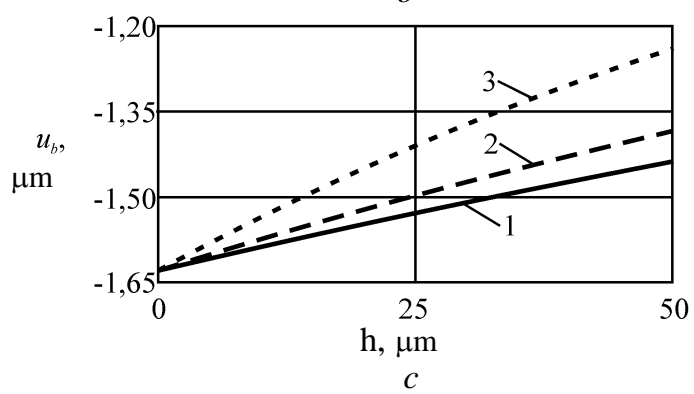

Fig. 5. Influencing the thickness $h$ of the coatings on the maximal von Mises' stress ( $a$ ) and the radial displacements on the internal (b) and external (c) surfaces of the cladding of fuel rods:

1 - external coating only; 2 - internal coating only; 3 - both internal and external coatings with the equal thicknesses

In the case of the internal and external coatings made from the same material with the same thicknesses $E_{a} h_{a}=E_{b} h_{b}$, but in any case the inequality $R_{a} a<R_{b} b$ provides the more noticeable influencing of the internal coating comparing with the same external coating.

It is important that influencing the thin coating on the stress-strain state of the cladding of fuel rods is defined by the multiply the Young's modulus and the thickness of the coating as can be seen from the boundary conditions (12), (13). Thus, increasing the Young's modulus of the coatings relatively the value (18) used for quantitative estimations in this research will lead to increasing of effect the thin coatings of the stress-strain stress and due to will be increase the strength and the rigidness of the cladding of fuel rods.

\section{CONCLUSIONS}

It is proposed the approach for estimating the impact of thin protective coatings on the stress-strain state of the thick-walled claddings of cylindrical fuel rods considering the axial symmetrical internal and external pressures from fission products and moving heat carrier 
in a nuclear reactor core. This proposed approach is based on the solution about the plane strain problem of the theory of elasticity for the axial symmetrical long cylinder with the specially constructed boundary conditions considering presence the thin coatings on the boundary surfaces of that cylinder.

The quantitative results obtained for the typical design the cladding of fuel rods closely similar to the WWWER-1000 nuclear reactor show clearly that the thin protective coatings have significant influencing on the stress-strain state in the domain of the cladding. Increasing the thickness of the thin protective coatings leads to decreasing the circumferential stresses and radial displacements in the cladding of fuel rods. It is important that the percent of increasing the sizes of the cladding due to making the thin coatings is significantly smaller than the percent of decreasing of the circumferential stresses and the radial displacements. Due to this circumstance, using the protective thin coatings is the effective approach to decrease the stresses and the displacements of the cladding of fuel rods under the operational conditions.

Theoretical researching shows that the protective coatings increase the strength and rigidness of the claddings of fuel rods. This theoretically prediction is in consistent with the published results [4] was obtained experimentally using the special measurements of the specimens. Increasing the strength and the rigidness of the cladding due to the thin coatings is the result of mechanical interacting between thick-walled and thinwalled structures representing the cladding and its coatings. Influencing the thin protective coatings on the cladding of fuel rods is similar to influencing of the elastic fixing like the Winkler's elastic foundation [17]. Thus, it is possible to believe that the thin-walled coatings must lead to increasing the strength and the rigidness of the thick-walled coated structures, although this assumption must be researched in each particular case.

The item in the boundary condition defining impact the thin coating is proportional the product of the Young's modulus and the thickness of the coating. Thus, it is possible to have the same increasing the strength and the rigidness of the cladding of fuel rods using the more thin coatings with the bigger the Young's modulus. This circumstance is very important for using structural materials cores of nuclear reactors considering with the special requirements on the neutron-physical characteristics.

The item in the boundary condition defining impact the thin coating is inversely proportional to the square of the curvature radius of the coated surface. Thus, the curvature of coated surface contributes to increasing the effect of thin protective coatings on the strength and the rigidness the cladding of fuel rods.

Simplified schematization of the loadings of the cladding of fuel rods reduced to the internal and external pressures allowed representing the coatings as the thin cylindrical shells without bending. In general case of loading the cladding of fuel rods it is necessary to use the general theory of thin shells to represent the thin coatings interacting with the thick-walled cladding. Development the general theory of mechanical interaction the thin protective coatings with the thickwalled claddings of fuel rods can be recommended for the future researches.

Simplified schematization of deforming the cladding of fuel rods and its coatings reduced to considering the elastic deformations under the given mechanical loadings cannot allowed to research the specific effects considering with influencing the temperature deformations, the plastic deformations, the creep, the irradiation effects on the operability of the cladding of fuel rods with the thin protective coatings. It is very important problem, because these specific effects can lead to damaging the protective thin coatings due to delamination for example and development this problem is recommended for the future researches.

In spite of presence the some simplifications and corresponding restrictions, the obtained theoretical results show that using the thin protective coatings can be very effective to increase the structural strength and the rigidness of the claddings of fuel rods of nuclear reactors in general and can be recommended to upgrade the fuel rods for operated nuclear reactors and to use in the future designs.

\section{REFERENCES}

1. N.A. Azarenkov, I.M. Neklyudov, V.N. Voyevodin. Reactor materials - modern status // Вісник Харківського начіонального університету. Сер. фіз. “Ядра, частинки, поля”. 2012, в. 3(1017), с. 4-18.

2. P. Hosemann, D. Frazer, M. Fratoni, A. Bolind, and M.F. Ashby. Materials selection for nuclear applications: Challenges and opportunities // Scripta Materialia. 2018, v. 143, p. 181-187.

3. J. Bischoff, C. Delafoy, C. Vauglin, P. Barberis, C. Roubeyrie, D. Perche, D. Duthoo, F. Schuster, J.-C. Brachet, E.W. Schweitzer, and K. Nimishakavi. AREVA NP's enhanced accident-tolerant fuel developments: Focus on Cr-coated M5 cladding // Nuclear Engineering and Technology. 2018, v. 50, p. 223-228.

4. P.I. Stoev, V.A. Belous, V.N. Voyevodin, A.S. Kuprin, S.A. Leonov, V.D. Ovcharenko, M.A. Tikhonovsky, and V.M. Khoroshih. Mechanical properties and acoustic parameters tubes of zirconium alloy $\mathrm{Zr} 1 \% \mathrm{Nb}$ with a protective coatings // Problems of Atomic Science and Technology. 2015, N 2(96), p. 8797.

5. R.M. Jones. Mechanics of composite materials. Philadelphia: "Taylor \& Francis", 1999, 519 p.

6. V.V. Vasiliev and E.V. Morozov. Mechanics and analysis of composite materials. Oxford: Elsevier, 2001, $412 \mathrm{p}$.

7. Bingbing Li and Tifeng Jiao (ed.). Nano/microstructured materials for energy and biomedical applications. Singapore: "Springer Nature Singapore Pte Ltd", 2018, 290 p.

8. V. Kompis (ed.). Composites with micro- and nano-structure. Springer Science + Business Media B.V., 2008, 300 p.

9. B.R.T. Frost. Nuclear fuel elements. Oxford: "Pergamon Press", 1982, 275 p. 
10. Тепловые и атомные электрические станции: Справочник / Под общ. ред. В.А. Григорьева, В.М. Зорина. М.: “Энергоатомиздат”, 1989, 608 с.

11. S. Timoshenko and S. Woinowsky-Krieger. Theory of plates and shells. New York: "McGraw-Hill Book Company", 1987, 580 p.

12. E. Ventsel and T. Krauthammer. Thin Plates and Shells. New York: "Marcel Dekker, Inc.”, 2001, 652 p.

13. S. Timoshenko and J.N. Goodier. Theory of elasticity. New York: "McGraw-Hill Book Company", $1951,506 \mathrm{c}$.
14. M.G. Lamé. Leçons sur la théorie mathématique de l'élasticité des corps solides. Paris: "GauthierVillars“, 1866, 364 p.

15. S. Timoshenko. Strength of materials. Part II: Advanced theory and problems. New York: "D. Van Nostrand Company, Inc.", 1947, 510 p.

16. R. Hill. The mathematical theory of plasticity. Oxford: Oxford University Press, 1998, 355 p.

17. K.L. Johnson. Contact mechanics. Cambridge: Cambridge University Press, 2003, 452 p.

Статья поступила в редакциию 04.11.2019 г.

\section{ОЦЕНКА ВОЗДЕЙСТВИЯ ТОНКИХ ЗАЩИТНЫХ ПОКРЫТИЙ НА НАПРЯЖЕННО-ДЕФОРМИРОВАННОЕ СОСТОЯНИЕ ОБОЛОЧКИ ТВЭЛОВ ЯДЕРНЫХ РЕАКТОРОВ}

\section{Э.В. Поволоцкий, Ю.В. Ромашов, А.Г. Мамалис}

Предложен подход к оценке влияния тонких защитных покрытий на напряженно-деформированное состояние толстостенных оболочек цилиндрических твэлов с учетом внутренних и внешних давлений от продуктов деления и движущегося теплоносителя в активной зоне ядерного реактора. Этот подход используется для количественных оценок влияния тонких покрытий, выполненных из нержавеющей стали, на напряженно-деформированное состояние оболочки из циркониевого сплава, используемого в ядерных реакторах ВВЭР-1000. Полученные теоретические результаты показывают, что использование тонких защитных покрытий может быть очень эффективным для повышения прочности конструкции и жесткости оболочек твэлов ядерных реакторов в целом и может быть рекомендовано для модернизации конструкций твэлов действующих ядерных реакторов и использования в будущих проектах.

\section{ОЦІНКА ВПЛИВУ ТОНКИХ ЗАХИСНИХ ПОКРИТТІВ НА НАПРУЖЕНО-ДЕФОРМОВАНИЙ СТАН ОБОЛОНКИ ТВЕЛІВ ЯДЕРНИХ РЕАКТОРІВ}

\section{Е.В. Поволоцький, Ю.В. Ромашов, А.Г. Мамаліс}

Запропоновано підхід до оцінки впливу тонких захисних покриттів на напружено-деформований стан товстостінних оболонок циліндричних твелів з урахуванням внутрішніх і зовнішніх тисків від продуктів ділення і рухомого теплоносія в активній зоні ядерного реактора. Цей підхід використовується для кількісних оцінок впливу тонких покриттів, виконаних з нержавіючої сталі, на напружено-деформований стан оболонки 3 цирконієвого сплаву, що використовується в ядерних реакторах ВВЕР-1000. Отримані теоретичні результати показують, що використання тонких захисних покриттів може бути дуже ефективним для підвищення міцності конструкції і жорсткості оболонок твелів ядерних реакторів у цілому і може бути рекомендовано для модернізації конструкцій твелів діючих ядерних реакторів і використання в майбутніх проектах. 